\title{
PERAN PEREMPUAN DALAM PENGEMBANGAN PROGRAM DESA WISATA
}

\author{
OLEH: \\ CADIKA INDRAWATI PUTRI ${ }^{1}$, RUDI SAPRUDIN DARWIS ${ }^{2}$, BUDI M. TAFTAZANI ${ }^{3}$ \\ 1. Mahasiswa Program Studi Sarjana (S-1) Kesejahteraan Sosial Fakultas Ilmu Sosial dan Ilmu Politik Universitas Padjadjaran \\ 2. Pusat Studi Kewirausahaan Sosial, CSR dan Pengembangan Masyarakat Fakultas Ilmu Sosial dan Ilmu Politik Universitas \\ Padjadjaran \\ 3. Departemen Kesejahteraan Sosial Fakultas Ilmu Sosial dan Ilmu Politik Universitas Padjadjaran
}

Email:

(cadikaindrawati@gmail.com; rsdarwis@unpad.ac.id; budimtunpad@gmail.com )

\begin{abstract}
ABSTRAK
Dalam pembangunan, perlu diupayakan peningkatan kapasitas dan partisipasi sumber daya yang ada untuk memaksimalkan pembangunan tersebut. Baik laki-laki maupun perempuan, sebagai sumber daya yang ada di dalam masyarakat, pada hakikatnya memiliki kesempatan yang sama untuk dapat berpartisipasi dalam pembangunan. Akan tetapi, pada kenyataannya, sering kita jumpai tidak samanya kesempatan antara laki-laki dan perempuan. Di samping perempuan dan laki-laki yang pada hakikatnya memiliki kesempatan yang sama, perempuan pun memiliki potensi besar untuk meningkatkan kapasitas dirinya. Di sini lah muncul pendekatan-pendekatan yang mengarah pada pemberdayaan perempuan. Dalam perkembangannya, partisipasi perempuan dalam proses pembangunan semakin terlihat, walaupun masih sering kita jumpai diskriminasi terhadap perempuan. Pada penilitian ini, peneliti akan meneliti seperti apa peran, partisipasi dan kedudukan perempuan dalam program desa wisata di Desa Sukaratu, Kecamatan Gekbrong, Kabupaten Cianjur, Provinsi Jawa Barat. Penelitian ini dilakukan dengan tujuan untuk dapat melihat potensi perempuan di pedesaan yang ikut berpartisipasi dalam pengembangan masyarakat di desanya, dalam hal ini, studi kasus program desa wisata di Desa Sukaratu. Hasil penelitian ini akan menjadi pengetahuan baru bagi studi pekerjaan sosial, khususnya mengenai pemberdayaan perempuan dan partisipasi perempuan dalam pembangunan desa.
\end{abstract}

Kata kunci: Perempuan, Pembangunan Desa, Desa Wisata

\begin{abstract}
In national development, efforts should be made to improve the capacity and participation of the existing resources to maximize the development. Both men and women, as resources within society, essentially have equal opportunity to participate in national development. However, in reality, we often encounter unequal opportunities between men and women. In addition to women and men who essentially have the same opportunity, women also have great potential to increase her capacity. Here are emerging approaches that lead to women's empowerment. In its development, women's participation in the national development process is increasingly visible, although we often encounter discrimination against women. In this research, the researcher will examine what role, participation and position of women in tourist village program in Sukaratu Village, Gekbrong District, Cianjur Regency, West Java Province. This research was conducted with the aim to see the potential of rural women who participated in community development in their village, in this case, the case study of tourist village program in Sukaratu Village. The results of this study will be a new knowledge for social work studies, especially regarding women's empowerment and women's participation in rural development.
\end{abstract}

Key words: Woman, Rural Development, Tourist Village 


\section{Pendahuluan}

Cianjur merupakan salah satu daerah di Jawa Barat yang memiliki banyak potensi wisata. Tercatat menurut situs tempatwisataindonesia.id, terdapat 42 tempat yang berpotensi menjadi tempat wisata, melihat fakta tersebut tentu dapat menjadi sebuah peluang pengembangan masyarakat dalam bidang ekonomi, dengan harapan kesejahteraan masyarakat akan meningkat dengan adanya beberapa daerah potensi wisata ini. Pengembangan masyarakat dengan segala kegiatan dan metodenya, memiliki tujuan utama yaitu untuk meningkatkan kesejahteraan masyarakat dalam berbagai aspek.

Terdapat sebuah program yang bertujuan untuk pengembangan masyarakat desa, yakni program desa wisata. Desa wisata adalah suatu bentuk integrasi antara atraksi, akomodasi dan fasilitas pendukung yang disajikan dalam suatu struktur kehidupan masyarakat yang menyatu dengan tata cara dan tradisi yang berlaku. (Nuryanti dan Wiendu. 1993). Hal terpenting dalam pengembangan masyarakat (termasuk program desa wisata) terletak pada terealisasikannya pemanfaatan semua sumber yang ada. Wanita merupakan sumber daya penting yang seharusnya dimanfaatkan dengan baik dalam kegiatan pengembangan masyarakat, khususnya masyarakat di pedesaan.
Pada tahun 2011, jumlah penduduk perempuan di Cianjur mencapai 1,065,691 jiwa (Data BPS Cianjur), dan pada tahun 2015, jumla penduduk perempuan mencapai 1,088,727 jiwa (Data BPS Cianjur). Melihat jumlah penduduk perempuan tersebut, dapat diketahui bahwa wanita dapat banyak turut berperan dalam pengembangan masyarakat desa. Akan tetapi wanita pada hakikatnya memiliki peran domestik yang tidak dapat dipisahkan dari peran-peran lain dalam kehidupannya. Hal ini menyebabkan wanita tidak dapat berfokus hanya pada peran publiknya. Dalam hal inilah terjadi sebuah dilemma di masyarakat akan kedudukan wanita dalam kegiatan bermayarakat khususnya pada program pengembangan masyarakat melalui program desa wisata.

Perlu dilakukan penelitian peran wanita dalam program desa wisata, guna melihat kedudukan wanita dalam pengembangan masyarakat melalui program desa wisata.

\section{Metode}

Penelitian ini menggunakan teknik penelitian studi kasus. Penelitian studi kasus merupakan pendekatan penelitian kualitatif dimana peneliti menyelidiki sebuah kasus atau beberapa kasus dari waktu ke waktu melalui pengumpulan data yang rinci yang melibatkan banyak sumber informasi (misalnya dengan 
observasi, wawancara, materi audiovisual, dan dokumen serta laporan), dan melaporkan deskripsi kasus tersbeut dan tema-tema berbasis kasus tersebut (Creswell, 2007, 73). Teknik pengumpulan data pada penelitian ini adalah dengan menggunakan wawancara mendalam, observasi dan studi dokumentasi.

Wawancara mendalam bertujuan untuk memperoleh keterangan dengan cara tanya jawab sambil bertatap muka antara pewawancara dengan informan atau orang yang diwawancarai secara terbuka yang memungkinkan nara sumber (responden) memberikan jawaban secara luas. Kedua belah pihakpun yaitu pewawancara dan informan terlibat dalam kehidupan sosial yang relatif lama.

Kemudian teknik pengumpulan data berikutnya adalah observasi, pada hakikatnya observasi merupakan kegiatan dengan menggunakan indera penglihatan, pendengaran, dan penciuman untuk memperoleh informasi yang diperlukan untuk menjawab masalah penelitian. Hasil observasi berupa aktivitas, peristiwa, objek, kondisi atau suasana tertentu dan perasaan emosi seseorang. Observasi dilakukan untuk memperoleh gambaran riil suatu peristiwa atau kejadian untuk menjawab pertanyaan penelitian (Guba dan Lincoln, 1981).

Teknik pengumpulan data berikutnya adalah studi pustaka, studi pustaka merupakan teknik pengumpulan data dengan cara mengumpulkan bahan-bahan bacaan, termasuk peraturan perundang-undangan, dokumen-dokumen yang memiliki keterkaitan dengan masalah penelitian. Cara ini dimaksud untuk mencari konsepsi-konsepsi, teori-teori, atau pendapat yang berhubungan dengan masalah penilitian.

Pada penelitian ini informan terdiri dari 2 sumber, yakni: 1.Pekerja sosial di Desa Sukaratu, Kecamatan Gekbrong, Kabupaten Cianjur, Provinsi Jawa Barat. 2.Para perempuan Desa Sukaratu yang terlibat dalam program desa wisata di Desa Sukaratu tersebut.

Analisis data pada penelitian ini dibagi menjadi 3 taap, yakni: reduksi data, penyajian data dan penarikan kesimpulan atau verifikasi. Reduksi data adalah analisis data yang diperoleh dari lapangan dilakukan dengan memilih hal-hal yang pokok, memfokuskan pada hal-hal yang penting, dicari tema dan polanya (Sugiono, 2007). Data yang diperoleh dari lapangan jumlahnya cukup banyak, sehingga perlu dicatat secara rinci. Semakin lama peneliti ke lapangan, maka jumlah data yang diperoleh akan semakin banyak, kompleks, dan rumit. Untuk itu perlu segera dilakukan analisis data melalui reduksi data.

Dengan demikian data yang telah direduksi akan memberikan gambaran yang lebih jelas, dan mempermudah peneliti untuk 
melakukan pengumpulan data selanjutnya, dan mencarinya apabila diperlukan.

Penyajian data dalam penelitian kualitatif berupa uraian singkat, bagan, hubungan antar kategori, dan sebagainya. Miles dan Huberman (Sugiono, 2007) menyatakan bahwa yang paling sering digunakan untuk menyajikan data dalam penelitian kualitatif adalah teks yang bersifat naratif.

Setelah data di lapangan direduksi dan kemudian data disajikan, tahap analisis data yang terakhir adalah penarikan kesimpulan. Kesimpulan yang diperoleh dari kedua tahap sebelumnya dapat berubah apabila tidak terdapat bukti-bukti yang kuat untuk proses pengumpulan data selanjutnya (Sugiono, 2007).

\section{Kesimpulan dan Saran}

Dari hasil penelitian awal menunjukan bahwa Cianjur memiliki potensi desa wisata yang baik, melihat jumla daerah dan jumlah sumber daya manusianya yang cukup banyak. Namun pada kenyataannya masyarakat desa di Cianjur belum mmapu mengoptimalkan potensi desa wisata dan jumlah sumber daya manusianya, terlebih lagi untuk sumber daya perempuannya, padahal jumlah perempuan dari tahun ketahun terus meningkat. Hal tersebut terjadi karena terjadi sebuah dilemma di masyarakat akan kedudukan wanita dalam kegiatan bermayarakat khususnya pada program pengembangan masyarakat melalui program desa wisata. Untuk itu hasil akhir dari penelitian ini akan menunjukan peran perempuan dalam program desa wisata.

Saran yang dapat diberikan pada penelitian ini adalah penumpulan data dengan berbagai metode yang telah disebutkan sebelumnya, harus dilakukan secara teliti, karena kesalahan pencarian data akan berakibat buruk pada hasil akhir penelitian.

\section{Daftar Pustaka}

Nuryanti, W. 1993. Desa Wisata. Concept, Perspective and Challenge. Yogyakarta : Gadjah Mada University Press.

Creswell, J. . (2007). Qualitative Inquiry \& Research Design: Choosing Among Five Approaches, 2nd ed. California : Sage Publication.

Lincoln, Y., and E. Guba. (1985). Naturalistic Inquiry. Newbury Park, CA: Sage Publications.

Raharjo, ST. 2015. Assessment untuk Praktik Pekerjaan Sosial dan Kesejahteraan Sosial. Bandung: Unpad Press 2015. Dasar Pengetahuan Pekerjaan Sosial. Bandung: Unpad Press. 2015. Keterampilan Pekerjaan Sosial: Dasar-dasar. Bandung, Unpad Press. 